\title{
Towards university-business cooperation: Key drivers, barriers and modes
}

\author{
Iga Rudawska, Joanna Kowalik
}

\begin{abstract}
A B S T R A C T
Objective: The purpose of this paper is to review the international evidence on the possible modes of university-business cooperation (UBC), analyse its main drivers, and identify barriers on the path of turning academia towards practice.

Research Design \& Methods: This work represents a synthesis of systematic reviews, peer-reviewed reports, individual empirical journal articles, predominantly published in the last ten years. Supplementary, a case study has been applied to present the project dedicated to UBC that has been run at the University of Szczecin.
\end{abstract}

Findings: The literature synthesis has revealed several crucial insights on the factors that facilitate or hinder university-business cooperation. Most of the studies highlight the importance of trustful relationships, that positively impact all cooperation activities. Moreover, all examined projects address the benefits for students and alumni of turning academia into practice. On the other hand, the review identified several barriers on the path of UBC development, focusing on connections, funding, organizational culture and internal characteristics.

Contribution \& Value Added: The contribution here is opening the mind concerning the possible modes of university-business cooperation, the barriers that need to be overcome and key drivers that stimulate the transfer of knowledge. The presented overview may be useful for improving educational policy, forming a higher education institutions' strategy, and making managerial decisions in HEls, especially in the emerging markets.

\begin{tabular}{ll}
\hline Article type: & literature review \\
Keywords: & university-business cooperation; entrepreneurial university; inno-
\end{tabular}

JEL codes: 123, M10

\section{Suggested citation:}

Rudawska, I., \& Kowalik, J. (2019). Towards university-business cooperation: Key drivers, barriers and modes. International Entrepreneurship Review (previously published as International Entrepreneurship / Przedsiębiorczość Międzynarodowa), 5(2), 91-105. https://doi.org/10.15678/IER.2019.0502.06 


\section{INTRODUCTION}

The EU "Europe 2020" strategy talks of smart, sustainable and inclusive growth, where an important role is assigned to active cooperation between universities and the business sector for the purposes of maintaining the Community's competitiveness (European Commission, 2010). Within this perspective, numerous modern higher education institutions (HEIs) should pursue a better responsiveness to the changes occurring around them, particularly in the labor market. The compatibility of curricula with labor market needs, and thus increasing the graduates' employability, is today becoming a requirement.

One of the manifestations of universities' efforts to adapt to the requirements of a competitive market is university-business cooperation (UBC). Despite the clear growth in interest in this cooperation observed in the 21st century, this phenomenon is not a completely new one. In 1993, Nelson described it in terms of an innovation system (Nelson, 1993), and a year later Gibbons' team pointed to it as a new mode of knowledge production (Gibbons, Limoges, Nowotny, Schwartzman, Scott \& Trow, 1994). UBC has also been referred to as "the triple helix model" (Etzkowitz \& Leydesdorff, 2000).

In turn, the term 'entrepreneurial university' was first used by B. Clark in 1998 (Clark, 1998), and nowadays he is considered as the one to have pioneered this concept (Sułkowki \& Seliga, 2016). In his research, he analyzed a number of case studies of HEls for their response to the signals received from and challenges posed by the surrounding reality. On this basis, he devised five characteristics of an 'entrepreneurial university' organization. These are: a strong central steering and leadership core, diversity in the funding base, an expanded development periphery, an integrated entrepreneurial culture and a stimulated academic heartland (Clark 1998). This term is close to the concept of a 'vibrant university', as well, which is defined as one that constantly revives environments of experience and involves, supports and motivates all university participants (i.e. the authorities, staff, students and PhD students, as well as surrounding entities) to undertake creative and entrepreneurial initiatives (Baran \& Bąk, 2016).

The Third Generation University (Makieła, 2017), as this model is often referred to, puts an emphasis on the need to change the management process. It has a decisive impact on the university's innovation and entrepreneurship processes that are aimed at commercializing research results. Therefore, cooperation with the surrounding world, particularly its business side, becomes an imperative. At the same time, such cooperation is an answer to demographic and cultural changes (including multiculturalism) and labor market globalization.

The university-business cooperation has been recently an intensive research field. Therefore, the purpose of our work is to to review the international evidence on the UBC, analyse its main drivers, and identify barriers on the path of turning academia towards practice.

\section{MATERIAL AND METHODS}

The main research questions have been formulated as follows: what is the rationale behind the idea of UBC? What are the principal conditions and sectoral key drivers that determine UBC and shape its nature?

Thus, our focus lay on synthesizing the motivation and benefits related to the application of UBC as a promising approach to entrepreneurship education. We carried out a desk research. 
The analysis has been based on the synthesis of systematic reviews, peer-reviewed reports and individual empirical journal articles. The authors conducted a critical literature review relating to university-business cooperation, concentrating on publications that explored the external and institutional factors that determine UBC and shape its nature. Additionally, one case study has been discussed to exemplify the modes of UBC, based on the running project at the University of Szczecin.

The paper is organized as follows: firstly the possible dimensions and range of UBC activates have been presented. Secondly, the possible drivers and barriers have been addressed. Next, the benefits of UBC have been highlighted. Finally, one example of UBC in action has been presented.

\section{LITERATURE REVIEW}

\section{UBC understanding and modes}

Higher education institutions (HEIs) and business have been cooperating for decades, transferring knowledge and know-how for their particular and more comprehensive, societal benefits. Recently, however, we do face a rise in academic, government and managerial discussions, referring this type of cooperation Hearly, Perkmann, Goddard \& Kempton, 2014; Hemmert, Bstieler \& Okamuro, 2014), brought on by policy and economic development. Additionally, more and more universities feel big pressure to attract private sponsors and deliver value base on reputation in an increasingly competitive environment (Galán-Muros \& Plewa, 2016; Perkmann et al., 2013).

The university-business cooperation is based on the concept of open innovation by Enkel, Gassmann \& Chesbrough, 2009). The idea behind it is not only to foster reputational and competitive advantage, but also to deliver fuel for innovation and economic development. Moreover, the implementation of innovations in HEls have a positive impact on all the education systems elements: components, functions and relationships. All stakeholders benefit of all these systemic changes. Three general outcomes of innovation in higher education occur (Epure, 2017): (1) the application of new technologies appears to be a facilitator of the transition from a department-centred vision to a student-centred vision of education; (2) innovation often stimulates a rapid development of partnerships between universities and other organisations, especially businesses; (3) innovations in HEls illustrate well two key aspects of the innovation process: 'doing new things' and 'doing existing things better'.

The second framework within UBC can be analysed is network approach. Universities and other HEls are understood as 'network organizations' that contribute to dynamic networks, in which companies also take part (Gulati, 1998; Snow, Miles \& Coleman, 1993)). Thus, UBC has been interpreted as any type of knowledge-intensive,formal and informal cooperative interactions between HEls and business for mutual interest and gain (Davey, Baaken, Gal an- Muros \& Meerman, 2011). It encompasses comprehensive cooperation activities, all of which are connected with one of the key mission of universities: research, education, and valorization (Galán-Muros \& Plewa, 2016).

In accordance with these developments, a fruitful stream of research has emerged, improving our understanding of relationship and interactions between business world and academia. The performed systematic literature review provides some important insights onto the state of current studies on UBC (table 1). 
Table 1. The insight into UBC understanding - the synthesis of literature review

\begin{tabular}{|c|c|}
\hline Author / study & Understanding of UBC \\
\hline $\begin{array}{l}\text { Cohen, Nelson \& } \\
\text { Walsh, } 2002\end{array}$ & - Focus on valorization activites, emphasizing patents and licenses \\
\hline $\begin{array}{l}\text { Smilor, O’Donnell, } \\
\text { Stein \& Welborn, } \\
2007\end{array}$ & $\begin{array}{l}\text { - Proactive approach to development } \\
\text { - Presence of a catalyst research university, organization and/or role model } \\
\text { - Research excellence and proportion of spinout companies and entrepre- } \\
\text { neurial start-ups }\end{array}$ \\
\hline $\begin{array}{l}\text { Bramwell \& } \\
\text { Wolfe, } 2008\end{array}$ & $\begin{array}{l}\text { - Commercialize knowledge produced by qualified research scientists } \\
\text { - Generating and attracting talents and providing formal and informal tech- } \\
\text { nical support with local business } \\
\text { - Entrepreneurship education (teaching and research), staff and student mo- } \\
\text { bility and internships, cooperative education } \\
\text { - Cooperation in curricula design }\end{array}$ \\
\hline \begin{tabular}{|l|} 
Boardman \& \\
Ponomariov, 2009
\end{tabular} & - Research partnership \\
\hline $\begin{array}{l}\text { Gibney, Lanham- } \\
\text { New, Cassidy \& Vor- } \\
\text { ster,2009 }\end{array}$ & $\begin{array}{l}\text { - Involvement in business representatives in university board structures or } \\
\text { vice-versa }\end{array}$ \\
\hline $\begin{array}{l}\text { Wonglimpiyarat, } \\
2010\end{array}$ & $\begin{array}{l}\text { - Focus on managing knowledge and establishing strong ties with well-estab- } \\
\text { lished companies in the early stages } \\
\text { - Focus on technology and infrastructure management, entrepreneurship } \\
\text { and new start-ups, as the collaboration matures }\end{array}$ \\
\hline $\begin{array}{l}\text { Guerrero \& Urbano, } \\
2010\end{array}$ & - Interdisciplinary centers and co-operation networks \\
\hline \begin{tabular}{|l|} 
Bathelt, Kogler \& \\
Munro, 2010 \\
\end{tabular} & - Science parks, business incubators, spin-offs (sponsored or unsponsored) \\
\hline $\begin{array}{l}\text { Landry, Saihi, Amara } \\
\text { \& Ouimet, } 2010\end{array}$ & $\begin{array}{l}\text { - Knowledge transfer activities such as collaboration on patents, teaching, } \\
\text { publications, informal exchanges and contribution to spinoff formation }\end{array}$ \\
\hline Poszewiecki, 2010 & $\begin{array}{l}\text { - Lectures delivered by business representatives delegated to the HEI } \\
\text { - Creation of their own enterprises by academic staff members } \\
\text { - Joint conferences and publications }\end{array}$ \\
\hline $\begin{array}{l}\text { Audretsch, Aldridge } \\
\text { \& Mark, } 2011\end{array}$ & $\begin{array}{l}\text { - Technology transfer offices } \\
\text { - Innovation accelerators } \\
\text { - High technology centers } \\
\end{array}$ \\
\hline $\begin{array}{l}\text { Mars \& Rhodes, } \\
2012\end{array}$ & $\begin{array}{l}\text { - Existence of student entrepreneurship programs } \\
\text { - Entrepreneurial teaching methodologies, having role models and reward } \\
\text { systems }\end{array}$ \\
\hline $\begin{array}{l}\text { Plewa, Gala'N-Mu- } \\
\text { ros \& Davey, } 2014 \\
\end{array}$ & - Curriculum design and delivery \\
\hline $\begin{array}{l}\text { Röigas, Seppo, Var- } \\
\text { blane \& Mohnen, } \\
2018\end{array}$ & $\begin{array}{l}\text { - Employee mobility, student mobility, joint R+D } \\
\text { - Commercialization of re-search results } \\
\text { - Practitioners' participation in the drawing up of curricula }\end{array}$ \\
\hline Davey, 2015 & $\begin{array}{l}\text { - Extending UBC orientation beyond teaching and research: engagement of } \\
\text { academics and students with businesses }\end{array}$ \\
\hline Pavlin, 2016 & $\begin{array}{l}\text { - Inter-company training courses } \\
\text { - Academic entrepreneurship in the form of business incubators and spin-offs } \\
\text { - Practitioners' participation in managing the HEI } \\
\text { - University professionals' participation in managing business }\end{array}$ \\
\hline
\end{tabular}

Source: own study. 
The above table demonstrates the evolution of UBC understanding. It highlights the shift from interpreting the UBC in the perspective of knowledge and patent transfer to treating it as a process of developing competencies with the respect to specific entrepreneurial attitudes and skills. It means that universities nowadays have to balance their regular academic duties and engagements with business word.

\section{Key drivers and barriers of UBC development}

University-business cooperation is never a single process. Instead, it can be seen as a collection of interactions of high complexity and diversity. It is determined by a number of macro-scale social and institutional variables. This is first and foremost a question of the general framework for action as set forth by, characteristic of the given country and reaching back to the given nation's history and culture. Also, the role of institutional support programs such as incentive schemes, public financing sustainability and awareness-raising actions, cannot be disregarded (Röigas et al., 2018,).

Bearing in mind the broad spectrum of UBC stakeholders, it appears to be of special significance to be able to shape the institutional awareness by promoting the cooperation concept itself, informing the parties of the benefits to be derived from the merging of the scientific and business worlds, and reinforcing the willingness to share knowledge. The last of these is strongly influenced by the level of one's awareness of how significant social ties are, and by the level of the system change leaders' trust and commitment. The willingness to share knowledge is also dependent on the organizational culture of the particular UBC stakeholders.

Another important element of the framework conditions for UBC development takes the form of such intermediary structures as the National Center for Research and Development or the Polish Agency for Enterprise Development. The quality of their work has an impact on the reduction of information asymmetries and transaction costs related to every deal.

Last but not least, UBC is affected by the compatibility of knowledge supply and demand, market demand and technology development and cultural attitudes towards industry-science relations (Polt, Rammer, Gassler, Schibany \& Schartinger, 2001).

According to the Community Innovation Survey that covered data from 14 European countries, enterprises must have a certain level of capabilities to enter into cooperation with higher education institutions (Röigas et al., 2018). The most frequently cited stimulants of UBC from the point of view of enterprises are:

- the development of R+D measured by the scope of research in various areas,

- the structure of the enterprise sector, namely the ratio of small and medium-sized enterprises (SME) to large corporations, including international ones,

- the intensity of intra- and inter-sectoral competition,

- the enterprises' absorption capacity measured by the effectiveness of innovation management,

- the scale of the enterprises' innovation depending on the stage of the innovation cycle.

On the other hand, from the point of view of the science sector, the level of cooperation with the business environment is affected by:

- the development of $R+D$ measured by the number of patents, 
- scientific excellence measured by the quality of publications and the reputation of the grants obtained,

- the structure of the scientific disciplines represented by the given $\mathrm{HEI}$,

- the capability to share knowledge, which is also affected by personal qualifications, the personnel's skills and the methods by which science is financed,

- the type of HEI (e.g. university, technical university, research institute).

Above mentioned factors let us to conclude that key drivers of UBC can relate to the environmental / institutional conditions, resource availability, and relationships (table 2).

Table 2. Key drivers and barriers to UBC development- the synthesis of literature review

\begin{tabular}{|c|c|}
\hline Author / study & Description \\
\hline \multicolumn{2}{|r|}{ Key drivers } \\
\hline Röigas et al., 2018 & $\begin{array}{l}\text { Favorable environmental conditions: legislation and sectoral } \\
\text { regulations; of institutional support programs }\end{array}$ \\
\hline D-Este \& Perkmann, 2011 & $\begin{array}{l}\text { Resource availability: business can increase expertise in } \\
\text { a new field, thus universities can access information on in- } \\
\text { dustry problems }\end{array}$ \\
\hline $\begin{array}{l}\text { Davey, Baaken, Gal_an-Muros, } \\
\text { V \& Meerman, 2011; Mora-Valen- } \\
\text { tin, Montoro-Sanchez, \& Guerras- } \\
\text { Martin, 2004; Plewa } 2009\end{array}$ & $\begin{array}{l}\text { Trustful relationships: the mutual trust and commitment, and } \\
\text { ongoing relations between partners can boost the cooperation }\end{array}$ \\
\hline \multicolumn{2}{|r|}{ Key barriers } \\
\hline Muscio \& Pozzali, 2012 & Poor connections: awareness and contacts (from both sides) \\
\hline Howells, Ramlog \& Cheng, 2012 & Lack of / or insufficient funding (public or private) \\
\hline $\begin{array}{l}\text { Koch, 2011; Muscio \& } \\
\text { Pozzali, } 2012\end{array}$ & $\begin{array}{l}\text { Organizational culture: } \\
\text { - motivations commonly differ dependent on different institu- } \\
\text { tional goals and norms } \\
\text { - the conception of time regarding goals, deadlines and results } \\
\text { is commonly different }\end{array}$ \\
\hline Arvanitis \& Woerter, 2015 & $\begin{array}{l}\text { Internal characteristics: businesses need confidentiality of } \\
\text { their innovations and if research is developed jointly with } \\
\text { universities companies often fear that confidential infor- } \\
\text { mation will be disclosed }\end{array}$ \\
\hline
\end{tabular}

Source: own work based on (Röigas et al., 2014) and (Galán-Muros \& Plewa, 2016).

As far as the barriers of developing UBC are concern, we can distinguish external and internal ones. The first group can be associated with the environmental conditions, and the second group - with the resources and capabilities of the partners. Based on the literature review, a large number of relevant factors emerged, that has been here brought together into the barriers relating to funding, connections, organizational culture differences and internal organizational characteristics (table 2).

Obstacles in UBC cooperation, that are comparable to the above highlighted barriers, have been also identified in the aforementioned EMCOSU project. The project findings concentrated on three groups of barriers to the development of UBC: barriers related to the intensity of bureaucracy, barriers related to limited resources and barriers related to 
differences in the organizational culture (Emcosu Project, 2015). The first groups of barriers originated from the complexity of procedures and the growing amounts of required documentation on both sides of the relationship. The second group of barriers was mainly related to $\mathrm{HR}$ and financial shortages. The third group of barriers resulted from differences in communication, time management and values.

\section{Benefits of UBC}

The idea behind university-business cooperation is to create various ties and relations in order to exchange and transfer knowledge between the parties. The growing public interest placed in UBC is built on the assumption that it impacts on the employability of graduates and contributes to teaching and learning improvements. First of all, UBC helps students and alumni to create and develop their skills, competencies and opportunities (table 3). Many international projects like HEGESCO, DEHEMS, EMCOSU support this assumption, delivering evidence that career success depends on the linkages between academia and business.

Table 3. An overview of skills, competencies and opportunities developed owning to UBC

\begin{tabular}{|l|l|}
\hline \multicolumn{1}{|c|}{ The type of the skill } & \multicolumn{1}{c|}{ Insights into the benefits } \\
\hline Communication skills & $\begin{array}{l}\text { Improving the ability to understand, express and interpret concepts, } \\
\text { thoughts, feelings, facts and opinions in both oral and written form }\end{array}$ \\
\hline Presentation skills & $\begin{array}{l}\text { Improving the set of techniques and skills that are required to success- } \\
\text { fully present information to others }\end{array}$ \\
\hline Self-management skills & $\begin{array}{l}\text { Improving the ability to control or redirect disruptive impulses and } \\
\text { moods and to suspend judgement - to think before acting }\end{array}$ \\
\hline Foreign language skills & $\begin{array}{l}\text { Improving the ability to understand oral messages, to initiate, sustain } \\
\text { and conclude conversations and to read, understand and produce texts } \\
\text { that are appropriate for the person's needs in a foreign language }\end{array}$ \\
\hline $\begin{array}{l}\text { Project management } \\
\text { skills }\end{array}$ & $\begin{array}{l}\text { Improving the ability to plan and manage project tasks and resources, and } \\
\text { communicate the progress and results within a defined period of time }\end{array}$ \\
\hline Problem-solving skills & $\begin{array}{l}\text { From a relational perspective: Improving the ability to find a common } \\
\text { ground and build rapport. From a task-oriented perspective: Improving } \\
\text { the the ability to define and outline problems and to seek the necessary } \\
\text { information for its resolution }\end{array}$ \\
\hline Teamwork skills & Improving the ability to collaborate with others in diverse group settings \\
\hline Experience & Acquiring more practical experience in a real-life project tasks \\
\hline Knowledge & Acquiring new special knowledge \\
\hline Learning by doing & Developing concrete concepts applicable in business practice \\
\hline Intercultural skills & Improving the ability to adopt oneself in an intercultural environment \\
\hline Thesis development & Making contacts for the final thesis \\
\hline CV development & Gaining an official practice partner certificate for project participants \\
\hline Career development & Making contacts for a future job \\
\hline
\end{tabular}

Source: own work based on: (Rossano et al., 2016).

Evidence to the assumption that UBC contributes to lifting student competences and graduate attractiveness in the labor market was provided also by the HEGESCO project (Allen, Pavlin \& Van der Velden, 2011). The studies on a large group of over 43 thousand graduates proved that their professional success and careers were closely linked to their alma mater's cooperation with its surrounding social and commercial environment. The 
opportunity to demonstrate professional experience (in the form of a record of practical placements and traineeships in enterprises), a stronger motivation and talent management skills are the outcomes that students involved in UBC projects during their studies can count on. Nevertheless, the conclusions drawn from this project were not optimistic: while almost every entrepreneur claimed that the practical orientation of university curricula was a must, only one in ten academics shared this opinion (Pavlin \& Svetlik, 2009).

A similar message was conveyed by research reports based on the long-term DEHEMS project, which covered the process of graduates entering the labor market and which subsequently followed their professional paths (Dehems Project, 2015). Problem-based learning, practical placements and student mobility and internationalization were found to increase postgraduate employability. Moreover, the research carried out within the DEHEMS consortium identified career success factors and influencing factors. The former group included satisfaction with one's work, career development opportunities, job security, compatibility of the graduate's qualifications with those expected by the employer, work autonomy and work-life balance. The latter group included the graduate's earlier professional experience, the type of their course of study, curriculum, teaching methods, their conduct in the course of their study, their country of origin and the characteristics of their position and of the employer. The general conclusion of this research was, however, that employers, trade unions and students alike voiced the expectation that universities should adopt a strategic orientation towards participatory management. Within this perspective, cooperation with various surrounding stakeholders is expected and desirable. It should be based on trustful relationships, public finance stability and institutional leadership promoting common research (Borrell-Damian, Morais \& Smith, 2014).

Similar conclusions were drawn by the researchers participating in an international consortium of Bulgaria, Hungary, Poland, Slovenia, Spain, Italy, Russia, Croatia and the Scandinavian countries. They studied a total of 397 businesses in the period between November 2013 and June 2014 (Emcosu Project, 2015). The analysis of their results reveals the existence of three approaches to UBC. The first one is related to support for the development of students' skills and professional careers by: cooperating with academic career services centers, entrepreneurs' participating in the work of alumni clubs and societies, and practitioners' contributing to the teaching process (by participating in developing the curricula, in lectures and in research).

The second one is related to strategic cooperation in respect of management, and could take the form of practitioners' involvement in HEI boards, or scientists' involvement in the supervisory boards of enterprises.

The third approach is oriented towards inciting innovation and creativity on both sides of such cooperation. This could take the form of operating business incubators, creating spin-offs and developing new businesses (Pavlin, 2016). The reports published by the EMCOSU researchers supported the assumption justifying university-business cooperation that is based on mutual benefits and knowledge transfer between the education sector and the business sector.

The revision of the results of the above mentioned projects let us confirm that the benefits of UBC lies within three areas: education, research and valorisation. University-business cooperation is first and foremost based on carrying out various sorts of educational training courses and traineeships in reputable companies with a possibility of further developing 
one's skills in the given enterprise under stable employment conditions. It can also entail the broadening and improving of knowledge by taking advantage of the operations of enterprises which are, in turn, interested in expanding their own knowledge at the higher education institution. Thanks to their active involvement in the work offered by enterprises, the students and young scientists often acquire practical skills and confront their knowledge with practice. For the enterprises, the students' knowledge and creativity are added value that may bring favourable benefits supporting the development of their businesses.

\section{PRACTICAL EXAMPLE OF UBC IN POLAND}

Putting into action one of the mentioned above mode of university-business cooperation, University of Szczecin introduced the project "Creative 2018". It focused on PhD student mobility and has been carried out under the program of the Minister of Science and Higher Education. The ministerial call "Dialogue" envisaged co-financing of measures undertaken within three domains, namely: "Scientific excellence", "Science for Innovation" and "The humanities for development" (Ministerstwo Nauki I Szkolnictwa Wyższego [MNiSW], 2018). Its purpose was to support measures contributing to the building of lasting relationships and cooperation between scientific bodies on the one hand and entities from the socio-economic environment on the other. Its originators planned the "Creative 2018" project to last for 21 months, and defined its main objective as "to increase the practical R+D project management skills of 40 young social sciences researchers (including a minimum of $50 \%$ of women and a minimum of $5 \%$ of disabled persons) and to commercialize their knowledge by organizing a comprehensive training and traineeship program adapted to the needs of the young scientists and the needs of the surrounding socio-economic environment entities of the West Pomeranian region", corresponding to the first two domains of action.

Young members of the University's academic staff (up to the age of 35) representing social sciences, i.e. economics, management, finance, political science, sociology, psychology and law, and willing to continue their career at an $\mathrm{HEl}$, made up a direct target group of 40 members. Each project participant was responsible for drawing up an individual program for traineeship in a reputable enterprise from the West Pomerania region that had earlier expressed its readiness to join the project. Such traineeship programs where then assessed by the Competition Jury composed of highly-regarded members of the University's academic staff, as well as chairpersons and directors from selected companies. The purpose of this cooperation was to establish ties between the academic environment and business.

As part of this cooperation, training courses in "Design thinking" for the participants were planned in order to improve their skills and shape their future professional career paths. The project contributed to the exchange of views and experience between the University and business, allowed for a confrontation with the commercial practice and facilitated future relationships between the scientific community and business, thus bringing mutual benefits. In the competition, the participants were able to show the skills they had acquired by preparing their individual traineeship programs to be implemented in the enterprise of their choice. As a result, the employer had the opportunity to choose to use the ideas of the ambitious participant, add his or her own vision to it and organize the young scientist's working time for a period of 6 months. 
Based on the experience gained from implementing the project "Creative 2018" the authors listed some new modes of university-business cooperation reflecting the specifics of PhD student mobility:

- promoting the idea of university-business cooperation: development by the project team of rules for the recruitment of young scientists for the training and traineeship program, development of rules for the operation of the project's Competition Jury taking into account the duties, tasks and assessment criteria, development of training and traineeship documentation including young scientist evaluation forms and individual forms concerning the training program, creation of a website for placing promotional and information materials concerning the project,

- practical workshop aimed at improving PhD students' soft skills in creative thinking; the workshop intends to provide a total of 1,920 hours of training to 40 young scientists of the University (48 hours per person) and makes use of the FRIS technique employing self-diagnosis of the participants' thinking and behavioral styles. This solution is devised to contribute to the merging of theory and practice,

- acquiring partners: thanks to the project manager's long-term experience and participation in various research grants the opportunity to cooperate with 6 reputable regional enterprises willing to join the program emerged,

- creative work on the individual traineeship program: out of the overall number of individual traineeship programs submitted by the training participants ( 40 persons), the Competition Jury selected 10 most creative ones that scored the most points; the winning authors commenced program implementation in the enterprises, and received an additional support in the form of 6 hours of coaching sessions,

- planning, implementing and monitoring of 10 traineeships: ultimately, 10 contracts for 6-month paid traineeships were signed with the program partners.

This example of a UBC project demonstrates numerous benefits to be gained. This type of exchange creates opportunities for working out extraordinary solutions and acquiring proven, trained and qualified employees, which as a result will contribute to lasting cooperation between students and enterprises, whereas the ties so established will facilitate both the parties' commitment to further projects and strengthen their mutual trust for any future purposes.

\section{CONCLUSIONS}

The literature review suggests that the sector of higher education is in constant pursuit of development, looking out for new initiatives that provide opportunities for the widening of operation range, the overcoming of barriers, and the creating of joint innovative solutions in cooperation with business sector.

The rationale behind UBC is to foster benefits for both engaged parties. For universities it means mainly enrichment of education, curriculum design and delivery, as well as upgrading students' employability skills. For companies in turn, it basically refers to knowledge transfer from academia and access to professional expertise. Moreover, for businesses, the students' creativity is seen as an added value that may bring advantages supporting the development. 
The overview has revealed several crucial insights on the factors that facilitate or hinder university-business cooperation. Most of the studies highlight the importance of trustful relationships, that positively impact all cooperation activities. It is line with previous research that shows that personal relationships are the most important factor in developing UBC (Siegel, Waldmann \& Link, 2003; Plewa, 2009), no matter the environmental conditions such as funding, institutional mechanisms and favourable law. UBC proves to have humanistic basis, depending on mutual trust, commitment and shared goals (Davey et al., 2011). Moreover, all examined projects stress out the importance of the access to complimentary resources, what has been previously confirmed in the literature (Bekkers \& Bodas Freitas, 2008; Tartari \& Breschi, 2011). On the other hand, the review identified several barriers on the path of UBC development, focusing on connections, funding, organizational culture and internal characteristics.

The conducted review gave also insights into common understanding of UBC activities. They can be divided into three main domains: research, education and valorisation. The first one encompasses mostly professional and student mobility as well as R\&D. the second one: curriculum design \& delivery and lifelong learning. The last one deals with commercialisation and entrepreneurship. The conducted synthesis revealed the evolution on the modes, towards commercialisation and entrepreneurship. The similar findings have been obtained by Plewa, Korff, Baaken \& Macpherson, 2013).

The review suggests that UBC is still in early stage of development in Europe, facing barriers to be overcome and a burning need to attract business interested in specific activities with mutual benefits. The science world is in constant pursuit of development, looking out for new initiatives that provide opportunities for the widening of horizons, the overcoming of barriers and the creating of joint innovative solutions in cooperation with enterprises. This result coincides with that obtained by Nowaczyk and Sobczak (2016).

The paper summarizes the current state of the university-business cooperation at European Union level. The contribution here is opening the mind concerning the possible modes of university-business cooperation, the barriers that need to be overcome and key drivers that stimulate the transfer of knowledge.

The paper has crucial implications for several stakeholders within the UBC system, especially in the emerging markets. The review stresses out the importance for HEls managers and policy makers of taking a comprehensive approach to UBC. The presented discussion may be useful for improving educational policy, forming a higher education institutions' strategy, and making managerial decisions in HEls. At all levels (European, national, as well as a regional) this means setting priorities that stimulate key drivers and reduce the barriers.

The review limits emerge from the self-selection of the projects and the scale of their implementation. Future research could concentrate on developing an objective measure of UBC and also focus on the perception of all UBC stakeholders. The perspective of academics could be enrich by the perspective of business people. This would enable comparative analysis, and as a result, better support managerial actions and policy development focused on comprehensive UBC portfolio. 


\section{REFERENCES}

Allen, J., Pavlin, S., \& Van der Velden, R. (Eds.). (2011). Competencies and early labour market careers of higher education graduates in Europe. Ljubljana: University of Ljubljana, Faculty of Social Sciences.

Arvanitis, S., Woerter, M. (2015). Exploration or exploitation of knowledge from univer-sities: does it make a difference? Economics of Innovation and New Technology, 24 (6), 596-623.

Audretsch, D., Aldridge, T. \& Mark, S. (2011). Social capital building and new business formation: a case study of the Silicon Valley. International Small Business Journal, 29 (2), 152-169.

Baran, G., \& Bąk, G. (2016). Społeczności i innowacje wibrującego uniwersytetu: Communities and innovation of Vibrant University. Przedsiębiorczość i Zarzq̨dzanie, 1 (17), 129-144.

Bathelt, H., Kogler, D. F. \& Munro, A. K.A (2010). A knowledge-based typology of university spin-offs in the context of regional economic development, Technovation, 30 (9-10), 519-532.

Bekkers, R., \& Bodas Freitas, I.M. (2008). Analysing knowledge transfer channels between universities and industry: to what degree do sectors also matter? Research Policy, 37 (10), 1837-1853.

Boardman, P. \& Ponomariov, BL. (2009). University researchers working with private companies. Technovation, 29 (2), 142-153.

Borrell-Damian, L., Morais, R., \& Smith, J.H. (2014). University-business collaborative research: goals, outcomes and new assessment tools. The Eulma collaborative research project report, Brussels, EUA publications.

Bramwell, A. \& Wolfe, D. A. (2008). Universities and regional economic development: the entrepreneurial University of Waterloo. Research Policy, 37 (8), 1175-1187.

Clark, B.R. (1998). Creating entrepreneurial universities: organizational pathways of transformation. Bingley: Emerald Group Publishing Limited.

Cohen, W.M., Nelson, R.R., \& Walsh, J.P. (2002). Links and impacts: the influence of public research on industrial R\&D. Management Science, 48 (1), 1-23.

D’Este, P., \& Perkmann, M. (2011). Why do academics engage with industry? The entrepreneurial university and individual motivations. Journal of Technology Transfer, 36 (3), 316-339.

Davey, T. (2015). Entrepreneurship at Universities - Exploring the Factors Influencing the Development of Entrepreneurship at Universities. Amsterdam: University-Industry Innovation Network Publishing.

Davey, T., Baaken, T., Gal_an-Muros, V., \& Meerman, A. (2011). Study on the Cooperation Between Higher Education Institutions and Public and Private Organizations in Europe. Brussels, Belgium: European Commission, DG Education and Culture.

Dehems Project (2015). Project Dehems: Network for the development of higher education management systems. International Consortium.

Emcosu Project Research Group (2014/2015). Emerging modes of cooperation between private sector organisations and universities. Ljubljana, University of Ljubljana, Centre for spatial sociology (coordination 2014). Slovenia, Ljubljana: University of Ljubljana, Social Science Data Archives.

Enkel, E., Gassmann, O., \& Chesbrough, H. (2009). Open R\&D and open innovation: exploring the phenomenon. R\&D Management, 39 (4), 311-316.

Epure, M. (2017). University-business cooperation: adapting the curriculum and educational package to labor market requirements, Proceedings of the 11th International Conference on Business Excellence, De Gruyter Publishing, 11 (1), 339-349.

Etzkowitz, H., \& Leydesdorff, L. (2000). The Dynamics of Innovation: From National Systems and “Mode 2 "' 'to a Triple Helix of University-Industry-Government Relations. Research Policy, 29(2), 109-123. 
European Commission (2010). Europe 2020. A strategy for smart, sustainable and inclusive growth. Retrieved from: https://eur-lex.europa.eu/legal-content/EN/ALL/?uri=celex:52010DC2020 on September 02, 2018.

Galán-Muros V., \& Plewa, C. (2016). What drives and inhibits university-business cooperation in Europe? A comprehensive assessment. R\&D Management, 46 (2), 369-382.

Gibney, M., Lanham-New, S., Cassidy, A. \& Vorster, H. 2009, Introduction to human nutrition, 2nd ed. San Francisco: Wiley-Blackwell.

Gibbons, M., Limoges, C., Nowotny, H., Schwartzman, S., Scott, P., \& Trow, M. (1994). The new production of knowledge: the dynamics of science and research in contemporary societies. London, England, Sage. Retrieved from: https://eurlex.europa.eu/legal\%20content/PL/TXT/PDF /?uri=CELEX:52010DC2020\&from=EN. on August 23, 2018.

Guerrero, M. \& Urbano, D. (2010). The Development of an entrepreneurial university. Journal of Technology Transfer, 37 (1), 43-74.

Gulati, R. (1998). Alliances and networks. Strategic Management Journal, 19 (4), 293-317.

Healy, A., Perkmann, M., Goddard, J., \& Kempton, L. (2014). Measuring the Impact of UniversityBusiness Cooperation. Luxembourg: Publications Office of the European Union.

Hemmert, M., Bstieler, L., \& Okamuro, H. (2014). Bridging the cultural divide: trust formation in university research collaborations in the US, Japan, and South Korea. Technovation, 34 (10), 605-616.

Howells, J., Ramlogan, R., \& Cheng, S.L. (2012). Universities in an open innovation system: a UK perspective. International Journal of Entrepreneurial Behaviour \& Research, 18 (4), 440-456.

Koch, T. (2011). Drivers and challenges in university industry collaborative research. EUIMA Workshop. Cambridge, United Kingdom, December 5-6.

Landry, R., Saihi, M., \& Amara, N., \& Ouimet, M. (2010). Evidence on how academics manage their portfolio of knowledge transfer activities. Research Policy, 39 (10), 1387-1403.

Makieła, Z. J. (2017). Model uniwersytetu trzeciej generacji XXI wieku - przedsiębiorczy, innowacyjny uniwersytet. Folia Oeconomica Cracoviensia, 58, 23-37.

Mars, M. \& Rhodes, G. (2012). Socially oriented student entrepreneurship: a study of student change agency in the academic capitalism context. Journal of Higher Education, 83 (3), 435-459.

Ministerstwo Nauki i Szkolnictwa Wyższego. (2018). Programy i inicjatywy. Retrieved from: https://www.gov.pl/web/nauka/dialog on August 22, 2018.

Mora-Valentin, E.M., Montoro-Sanchez, A., \& Guerras-Martin, L.A. (2004). Determining factors in the success of R\&D cooperative agreements between firms and research organizations. $R e$ search Policy, 33 (1), 17-40.

Muscio, A., \& Pozzali, A. (2012). The effects of cognitive distance in university-industry collaborations: some evidence from Italian universities. The Journal of Technology Transfer, 37 (3), 1-23.

Nelson, R. (Ed.). (1993). National innovation systems. A comparative analysis. New York, Oxford: Oxford University Press.

Nowaczyk, G., \& Sobczak, A. (2016). Role of entrepreneurship education in higher education institutions in the process of business development in Poland. International Entrepreneurship / Przedsiębiorczość Międzynarodowa, 2 (2), 43-52.

Pavlin, S. (2016). Considering university-business cooperation modes from the perspective of enterprises. European Journal of Education, 58 (1), 25-39.

Pavlin, S., \& Svetlik, I. (2009). Future development of higher education. In Pavlin, S. (Ed.), Report on the qualitative analysis of higher education institutions and employers in five countries: Devel- 
opment of competencies in the world of work and education. Hegesco project. Ljubljana, University of Ljubljana. Retrieved from: http://www.decowe.org/static/uploaded/htmlarea/finalreportshegesco/Qualitative_Analysis of_HEls_and_Employers_in_Five_Countries.pdf. on August 23,2018.

Perkmann, M., Tartari, V., McKelvey, M., Autio, E., Brostroem, A., D’Este, P., Fini, R., Geuna, A., Grimaldi, R., Hughes, A., Krabel, S., Kitson, M., Llerena, P., Lissoni, F., Salter, A., \& Sobrero, M. (2013). Academic engagement and commercialization: a review of the literature in university industry relations. Research Policy, 42 (2), 423-442.

Plewa, C. (2009). Exploring organizational culture difference in relationship dyads. Australasian Marketing Journal, 17 (1), 46-57.

Plewa, C., Gala'N-Muros, V. \& Davey, T. (2014) Engaging business in curriculum design and delivery: a higher education institution perspective. Higher Education, 70, 1-70.

Plewa, C., Korff, N., Baaken, T., \& Macpherson, G. (2013). University-industry linkage evolution: an empirical investigation of relational success factors. R\&D Management, 43 (4), 365-380.

Polt, W., Rammer, C., Gassler, H., Schibany, A., \& Schartinger, D. (2001). Benchmarking industry science relations: the role of framework conditions. Science and Public Policy, 28 (4), 247-258.

Poszewiecki, A. (2010). Budowa strategii współpracy jednostek naukowych z biznesem. Analiza wybranych przypadków. In Poszewiecki, A. (Ed.), Budowa współpracy nauki z biznesem w Województwie Lubelskim (pp. 73-86). Warszawa: Instytut Badań nad Demokracją i Przedsiębiorstwem Prywatnym.

Röigas, K., Seppo, M., Varblane, U., \& Mohnen, P. (2018). Which firms use universities as cooperation partners? - the comparative view in Europe. University of Tartu. Retrieved from https://majandus.ut.ee/sites/default/files/mtk/dokumendid/febawb93.pdf. on August 23, 2018.

Rossano, S., Meerman, A., Kesting, T. \& Baaken, T. (2016). The Relevance of Problem-based Learning for Policy Development in University-Business Cooperation. European Journal of Education, 51 (1), 40-55.

Siegel, D.S., Waldmann, D., \& Link, A. (2003). Assessing the impact of organizational practices on the relative productivity of university technology transfer offices: an exploratory study. Research Policy, 32 (1), 27-48.

Smilor, R., O'Donnell, N., Stein, G., \& Welborn, R. S., III (2007). The research university and the development of high-technology centers in the United States. Economic Development Quarterly, 21 (3), 203-222.

Snow, C.C., Miles, R.E., \& Coleman, H.J., Jr. (1993). Managing 21st century network organizations. Organizational Dynamics, 20 (3), 5-20.

Sułkowski, Ł., \& Seliga, R. (2016). Przedsiębiorczy uniwersytet - zastosowanie zarządzania strategicznego. Prace Naukowe Uniwersytetu Ekonomicznego we Wrocławiu, 444, 478-489.

Tartari, V., \& Breschi, S. (2011). Set them free: scientists' evaluations of the benefits and costs of university industry research collaboration. Industrial and Corporate Change, 21 (5), 1117-1147.

Wonglimpiyarat, J. (2010) Commercialization strategies of technology: lessons from Silicon Valley. Journal of Technology Transfer, 35 (2), 225-236. 


\section{Authors}

Contribution share of authors amounts to $70 \%$ I. Rudawska and to $30 \% \mathrm{~J}$. Kowalik.

\section{Iga Rudawska}

Head of the Department of Economics, Institute of Economics and Finance. Her research interests include entrepreneurship, health economics and health care management.

Correspondence to: Prof. dr hab. Iga Rudawska, Faculty of Economics, Finance and Management, University of Szczecin, 71-101, Poland, e-mail: iga.rudawska@usz.edu.pl

ORCID (1) http://orcid.org/0000-0002-2173-931X

\section{Joanna Kowalik}

PhD student at the Department of Economics, Institute of Economics and Finance. Her research interests include health economics and Economic analysis.

Correspondence to: Mgr Joanna Kowalik, Faculty of Economics, Finance and Management, University of Szczecin, 71-101, Poland, e-mail: joanna.kowalik@usz.edu.pl

ORCID (1) http://orcid.org/0000-0002-5152-554X

\section{Acknowledgements and Financial Disclosure}

The article is financed within the framework of the program of the Minister of Science and Higher Education under the name "Regional Excellence Initiative" in the years 2019-2022, project number 001/RID/2018/19, the amount of financing PLN 10,684,000.00.

Legal Notice: Part of this work has been presented during the 11th ICEBE \& 7th ICIE \& PEESA III International Conference on Engineering and Business Education, Innovation and Entrepreneurship and Capacity Building in Higher Education on October 15-18, 2018 (Szczecin, Poland) and has been available in conference proceedings.

\section{Copyright and License}

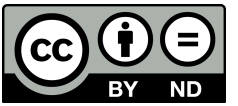

This article is published under the terms of the Creative Commons

Attribution - NoDerivs (CC BY-ND 4.0) License

http://creativecommons.org/licenses/by-nd/4.0/

Published by the Centre for Strategic and International Entrepreneurship - Krakow, Poland

Ministry of Science and Higher Education Republic of Poland
The journal is co-financed in the years $2019-2020$ by the Ministry of Science and Higher Education of the Republic of Poland in the framework of ministerial programme "Support for Scientific Journals" (WCN) on the basis of contract no. 238/WCN/2019/1 concluded on 15 August 2019. 
